\title{
John Chrysostom on Manichaeism
}

\begin{abstract}
Author:
Chris L. de Wet ${ }^{1,2}$ (D)

Affiliations:

${ }^{1}$ New Testament and Early

Christian Studies,

Department of Biblical and

Ancient Studies, University

of South Africa, Pretoria,

South Africa
\end{abstract}

${ }^{2}$ Australian Lutheran College, University of Divinity,

Adelaide, Australia

Corresponding author:

Chris de Wet,

dwetcl@unisa.ac.za

Dates:

Received: 26 Apr. 2019

Accepted: 17 June 2019

Published: 04 Sept. 2019

How to cite this article:

De Wet, C.L., 2019,

'John Chrysostom on

Manichaeism', HTS Teologiese

Studies/Theological Studies

75(1), a5515. https://doi.org/

10.4102/hts.v75i1.5515

\section{Copyright:}

C 2019. The Authors. Licensee: AOSIS. This work

is licensed under the

Creative Commons

Attribution License.
Read online:

Scan this QR
code with your
smart phone or
mobile device
to read online.

This article examines John Chrysostom's (ca. 349-407 CE) statements about Manichaeism. The study enquires regarding the extent of Chrysostom's knowledge of Manichaean beliefs and practices, and whether he possibly had contact with Manichaeans. The study is not so much interested in determining how accurately or inaccurately Chrysostom understands and characterises Manichaeism, although at some points the analysis does venture into some of these issues. In the first instance, Chrysostom's views about Manichaean theology and, especially, Christology are delineated. Proceeding from the negative evaluation of the material cosmos in Manichaeism, the study then looks at Chrysostom's critique of Manichaean views of the body, especially as it relates to freedom of choice. Chrysostom's accusations of Manichaean practices, namely, starving as salvation and the accusation of castration, are also examined. Finally, Chrysostom's response to the Manichaean rejection of a corporeal resurrection is analysed, after which some conclusions are drawn.

Keywords: John Chrysostom; Manichaeism; Late antiquity; Corporeal resurrection; Practices of Manichaeans.

\section{Introduction ${ }^{1}$}

John Chrysostom, the prolific preacher who later became the bishop of Constantinople in the early 5th century CE, was probably no stranger to Manichaeism. ${ }^{2}$ Having been born and raised in Syrian Antioch most of his life, ${ }^{3}$ he regularly rebukes Manichaeans in his homilies and treatises. ${ }^{4}$ Besides Chrysostom, we know of several other historical sources attesting to the presence of persons adhering to the Manichaean faith Antioch (Brown 1969:92-103; Lieu 2015:26-131; Woods 2001:255-264). The purpose of this article is to examine Chrysostom's claims ${ }^{5}$ on the nature of Manichaeism and the practices of Manichaeans. The study is not so much interested in determining how accurately or inaccurately Chrysostom understands and characterises Manichaeism, although at some points the analysis will venture into some of these issues. It is commonly known that the polemics of late antique Christian heresiology was least concerned with accurate and fair descriptions and judgements of non-orthodox opponents.

\section{John Chrysostom's knowledge about Manichaeism}

Chrysostom is, broadly speaking, aware of the complex Manichaean pantheon and Manichaean dualism, and how it differs from other, apparently similar, views. In reference to 2 Corinthians 4:4, and the notion of the 'god of this world', Chrysostom states (In epistulam II ad Corinthios homilia 8.2; for the Greek text, see Field 1845:3:101):

But who is the 'god of this world'? Those that are diseased with Marcion's ideas, declare that this is said referring to the Creator, the just only, but not good. For they say that there is a certain God, just but not good. But the Manichaeans say that the devil is meant here, wanting to introduce, from this passage, another creator of the world besides the true One, quite senselessly.

Although Chrysostom often groups Marcionism and Manichaeism together, he shows here that he has some idea of the theological differences between these movements. Furthermore, when we look 1.A version of this article was presented as a paper at a conference with the theme, 'Manichaeism and Early Christianity., co-organised
by Prof. Johannes van Oort and Prof. Chris De Wet, $23-25$ March 2019, University of Pretoria. I especially thank Johannes van Oort, Nils
Arne Pedersen, Michel Tardieu, lain Gardner and Jason BeDuhn for their comments on the paper and our discussions about Arne Pedersen, Michel Tardieu, lain Gardner and
Manichaeism, more generally, during the conference.

2.It is not the purpose of this study to provide an overview of Manichaean beliefs and practices. Excellent studies on this have already been done is several excellent studies (see for instance, BeDuhn 2000; Coyle 2009; Lieu 1992, 2008; Tardieu 2008). On Augustine and Manichaeism, see esp. BeDuhn (2013a, b). It should also be noted that this study is not concerned with comparing Chrysostom's views about Manichaeism with those of Augustine, which is a topic for another time and not within the scope of this article.

3.On the life of John Chrysostom, see, for instance, Kelly (1998) and Brändle (2004).

4.Some initial comments on Manichaeism in Chrysostom's thought are made by Mara (2008:195-199) and De Wet (2014:30-36)

5.All translations from John Chrysostom's works are my own unless otherwise indicated.

Note: The collection entitled 'Christina Landman Festschrift', sub-edited by Wessel Bentley (University of South Africa) and Victor S. Molobi (University of South Africa). 
at other Manichaean-Christian exchanges, especially between Augustine and Faustus, we know that this text was often used as a proof-text for Manichaean dualism (BeDuhn 2007:95). Chrysostom is therefore knowledgeable of what we might call the economy of proof-texting among different alternative Christian groups, and he prepares his audience accordingly.

\section{Christology}

A great deal of Chrysostom's theological polemic against Manichaeism is reserved for refuting Manichaean Christology. The first issue relates to the incarnation of Christ. The most detailed description of the docetic tendencies in Manichaeism and similar movements is found in Chrysostom's homily against Marcionism and Manichaeism, in which he states (In illud: Pater, si possible est, transeat 3; Greek text in Migne 1862:51:37-38): ${ }^{6}$

If then after all these things [in the Gospel accounts] have occurred, the evil mouth of the devil, speaking through Marcion of Pontus, and Valentinus, and Manichaeus of Persia, and many more heretics, has attempted to subvert the doctrine of the incarnation and has asserted a satanic utterance saying that He did not become flesh, nor was clothed with it, but that this was mere

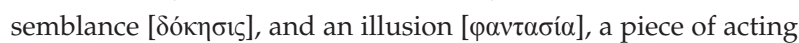

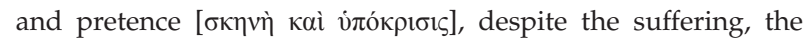
death, the burial, the thirst, crying aloud against this teaching.

We again observe the pattern of comparing doctrines between Marcionites, Manicheans and Valentinians, this time highlighting their similarities in terms of Docetism, with Chrysostom using the technical terms signified by it (e.g.

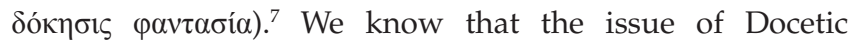
Christology in Manichaeism is a complex matter (Franzmann 2003:77-78), but Chrysostom does not hesitate to generalise all the Christologies of Manichaeism and the other groups he

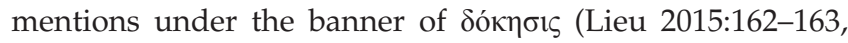
204, 222 has shown a similar tendency with other Eastern Christian authors).

Moreover, Chrysostom devoted a significant amount of attention to the problem of volition and freedom of choice, both that of Christ and of humanity, in Manichean thought, which is also evident in Augustine (BeDuhn 2013a:284-285; Wilson 2018:293-298). The idea that there is one divine will because there is only one divine Person is somewhat common among groups with a docetic Christology (Harkins 1984:106). This issue about freedom of will is a major theme in Chrysostom's homily against the Marcionites and Manichaeans. In response to his Manichaean opponents, Chrysostom believed that 'Christ is one divine Person possessing two natures and two wills, of which the one nature

6.This is the one homily of Chrysostom that is specifically directed against the

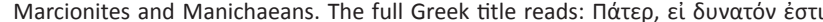

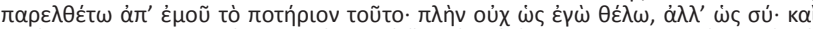

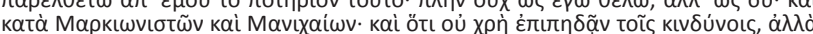

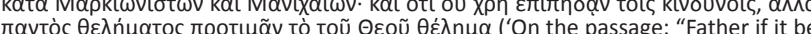

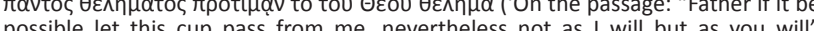
possible let this cup pass from me, nevertheless not as I will but as you will" [Matthew 26:39//Luke 22:42]: and against Marcionites and Manichaeans; also, that we should not to rush into danger, but choose the will of God before every other
will' [CPG4369]).

7.On the phenomenon of Docetism in early Christianity more generally, see several essays in Verheyden et al (2018). and will are divine, while the other nature and will belong to him as true man. Each nature and will has its own proper activities' (Harkins 1984:206; see also Laird 2012:87-88).

\section{Cosmology and the body}

The next polemical premise against the Manichaeans is their view of the cosmos and the body, which Chrysostom understands as being absolutely pessimistic. In one of his homilies on Genesis, Chrysostom states (In Genesim homilia 2.3; trans. Hill 1999:37; Greek text in Migne 1862:53:29): 'Even if Mani accosts you saying matter pre-existed, or Marcion, or Valentinus, or pagans, tell them directly: "In the beginning God made heaven and earth"'. This is a very interesting occurrence in Chrysostom's thought. Here, and in some other instances, Chrysostom prescribes what almost looks like a mantra - the instinctive repetition of Genesis 1:1, against the Manichaeans. In his 49th homily on Matthew, Chrysostom reinterprets the miracle of the multiplication of the fish and the loaves of bread (Mt 14) as a creation story, in which Christ demonstrates, on the one hand, the creative power of God, and on the other, the fact that his creation is good and beneficial. Chrysostom states (In Matthaeum homilia 49.2; Greek text in Migne 1862:58:498):

And why does he not create them [i.e. the fish and the loaves] from nothing? Stopping the mouth of Marcion, and the Manichaeans, who alienate His creation from Him, and teaching by His very works, that surely all the visible things are His works and creatures, and demonstrating that it is He who provides the fruits, who said at the beginning, 'Let the earth sprout vegetation', and 'Let the waters bring forth moving creatures with living souls'. For this is not at all an inferior work compared to the other. For although those were made out of things that do not exist, yet they were still from the water. And it was no greater feat to produce fruits out of the earth, and moving living things out of the water, than out of five loaves to make so many; and in reference to the fishes, again, which was a sign that He was the ruler both of the earth and of the sea.

The fact that Christ creates by means of multiplication, rather than creating ex nihilo (which God has done), is evidence that the divine Christ, the good Creator God, is ruler over his creation. Once again Chrysostom here brings together views of Marcionism and Manichaeism.

Directly related to Manichaean cosmic pessimism is, according to Chrysostom, their perceived corporeal pessimism. Chrysostom is aware of the Manichaean belief of the dispersion of the divine light substance in the world, especially in certain foods (Van Oort 2013:1-8). Chrysostom accuses the Manichaeans of 'introducing the substance

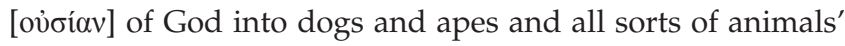
(In diem natalem 6; Greek text in Migne 1862:49:359). This apparent tension between corporeal pessimism and the substantial presence of the divine in the world does not seem to bother Chrysostom. He vilifies Manichaeans as persons who not only hate the body, but as actively warring against it through rigorous ascetic practices in which fasting borders on starvation and sexual abstinence mirrors castration. 


\section{Fasting}

With regard to fasting, Chrysostom perceives Manichaean dietary regulations not as a case of cosmic appreciation (which is perhaps closer to what Manichaean writings attest), but rather as disdain and animosity. In another homily on Matthew, he draws an interesting distinction between Christian monastic values and the values of Manichaean monks with regard to fasting and food, stating (In Matthaeum homilia 55.6; Greek text in Migne 1862:58:547):

Therefore they [i.e. Christian monks] say, 'Glory be to You, O Lord, glory be to You, O Holy One, glory be to You, O King, that You have given us food to delight us'. For we ought to give thanks not only for the greater things, but also for the lesser things. And they do also give thanks for these lesser things, bringing the heresy of the Manichaeans in disrepute, and many of those who profess our current life to be evil. For it is not that you should hold them [i.e. Christian monks] in suspicion, by their high selfdiscipline and contempt for the stomach, as abhorring [ $\beta \delta \varepsilon \lambda \nu \tau \tau o \mu \varepsilon \dot{v} \omega v]$ the food, like the aforementioned heretics, who almost starve themselves to death [ár $\alpha \gamma \chi 0 v i \zeta o ́ v \tau \omega v]$. They teach you by their prayer that they abstain not from an abhorrence of

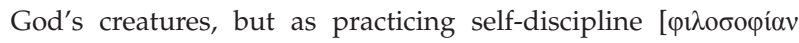
$\dot{\alpha} \sigma \kappa o v ̃ v \tau \varepsilon \zeta]$.

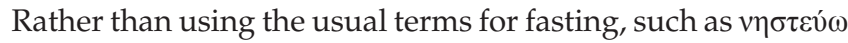
[I fast] and $\dot{\alpha} \pi \varepsilon \dot{\chi} \chi$ [I abstain], he uses the word $\dot{\alpha} \pi \alpha \gamma \chi 0 v i \zeta \omega$ [I starve], as hyperbole, to describe Manichaean fasting. This is a term he often uses in his works to describe any form of rigorous fasting, especially that of the Manichaeans, which he considers heretical (see also Chrysostom, In epistulam ad Titum 1.4; De sacerdotio 3.13). It should be remembered in this instance that Chrysostom mostly speaks to urban audiences, among whom he was promoting a more moderate and popular form of asceticism (De Wet 2019:410-463). The preacher understands (or perhaps, misunderstands) Manichaean fasting, then, not as being motivated from selfdiscipline (he uses the term pi $\lambda$ oбopía here), but because of their abhorrence of edible material.

Chrysostom is perhaps only halfway correct. Scholars like BeDuhn (2000:213-215) and Van Oort (2013:1-8) have shown that the dietary and fasting practices of the Manichaean elect were not so much motivated from a perspective of corporeal pessimism or even corporeal mortification, which is actually closer to Chrysostom's own view of fasting (De Wet 2019:432446; Shaw 1998:131-139). Nor was their fasting motivated from an attitude of animosity towards the food itself. Beduhn (2000) explains:

Far from Manichaean discipline aiming to replace consumption, it had its own end in consumption ... By fasts, the Elect both prepare their bodies for the meal and, after the meal, process the ingested food toward salvation rather than redispersing it. Fasting produces 'angels' from the food, who ascend to heaven. Manichaean disciplines should be described not as mortification, but as vivification. (p. 214)

Van Oort (2013:4) explains that Manichaeans considered food 'beautiful and splendid and bright because of their light substance'. This is not how Chrysostom perceived it. He saw the Manichaeans as rigorous ascetics, basically starving themselves, because of their hate of foodstuffs, the body and matter more generally.

\section{Castration?}

Not only do the Manichaeans starve themselves, in Chrysostom's view, but they are also guilty of corporeal mutilation and even, possibly, castration. A most interesting reference occurs in the fifth homily of Chrysostom's commentary on Galatians. While discussing Galatians 3:12, in which the Apostle Paul shares his wish that those promoting circumcision among Gentile Christians have the knife slip and castrate themselves, Chrysostom states (In epistulam ad Galatas commentaries 5.3; Greek text in Field 1852:4:83):

If they wish, let them not only be circumcised, but mutilated

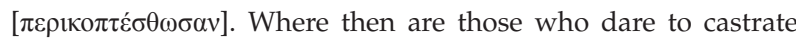

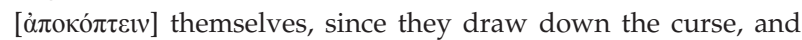

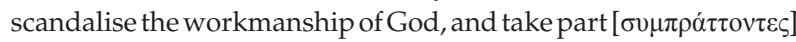
with the Manichaeans? For the latter call the body treacherous

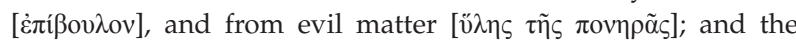
former by their deeds provide a pretext to these miserable

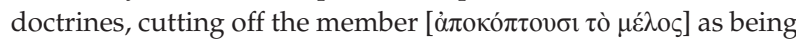
hostile and treacherous. Ought they not much more to gouge out the eyes, for it is through the eyes that desire enters the soul? But in truth neither the eye nor any other part of us is to blame,

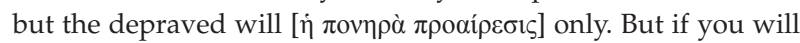
not allow this, why do you not cut out the tongue for blasphemy, the hands for theft, the feet for their evil courses and, as to say, the whole body?

This text is somewhat ambiguous on various levels. Chrysostom does not directly say that the Manichaeans castrate themselves. He rather implies that those persons who castrate themselves, even those who practise circumcision, provide a pretext for Manichaean corporeal pessimism. It is not clear whether Chrysostom means that Christians who castrate themselves join Manichaeans in the practice of castration or simply in the view that the body is evil and treacherous. Chrysostom's use of the term $\sigma 0 \mu \pi \rho \alpha ́ \sigma \sigma \omega$ might imply an instance of someone joining together in the practice of another, but it remains somewhat ambiguous. A highly similar yet equally ambiguous discussion is found in his 49th homily on Matthew (De Wet 2015:263-264). It could simply be another case of invective hyperbole for the sexual abstinence practised by Manichaeans, as with the equation of fasting and starvation.

There is indeed evidence for the practice of self-castration among early Syrian Christian communities. In Bardaisan's Book of the Laws of the Countries, there is a reference to King Abgar of Edessa, who apparently outlawed castration (Caner 1997:396-415; Shahîd 1984:99). Some slightly later sources, like the Canon of Rabbula 55, read: 'No one from among the sons of the church, those who call upon themselves the name of Christ, shall dare to castrate himself' (Phenix \& Horn 2017:113). A Syriac letter from the Collection of Severus of Antioch makes a similar prohibition. Many of the references to self-castration in Roman Syria and Mesopotamia should 
also be read within the context of the cult of Atargatis, or Dea Syria, in which self-castration was a feature (Lollar 2018:75-106). ${ }^{8}$ Overall, castration was a very prominent discourse in this area. I could not find any 4th- or early 5th-century references to Manichaean castration. There are some scattered references to a certain radical Manichaean ascetic from the early Islamic period, known as Meşallyāne, but he seems to be an exception, and other Manichaeans rejected his behaviour. It should not, however, surprise us if there were Manichaeans in Syria and Mesopotamia who practised, along with some Christian monks, self-castration. But the issue remains uncertain (De Wet 2015:263-264). The fact that Manichaeans, especially the Elect, were against harming any living creature might count against the occurrence of castration among Manichaeans (BeDuhn 2013b:78-81; Kósa 2015:255-268).

What is not uncertain is that for Chrysostom - whether one actually mutilates the body through starvation or castration is beyond the point - the fact that the Manichaeans harbour such an abhorrence, in his view, towards the body is not very different from practising such extreme forms of corporeal discipline. Even if Manichaeans did not castrate themselves, Chrysostom would say, they might as well do it. Chrysostom even accuses the Manichaeans for performing exegetical corporeal mutilation, in that they mutilate the Pauline corpus of scripture (In epistulam II ad Corinthios 21.4; Greek text in Field 1845:3:223):

And despite many heretics having attempted to cut him [Paul] into pieces, yet still, even though dismembered, he displays a mighty strength. For both Marcion and Manichaeus certainly use him, but only after cutting him into pieces. But still even so they are refuted by the several body parts. For even a hand alone of this champion being found among them utterly defeats them; and a foot alone, left among others, pursues and wears them out.

For Chrysostom, the Manichaean disdain for the physical body is mirrored in their misuse of the scriptural body. Manichaean exegesis is likened to scriptural mutilation, a form of invective often also applied against Jewish and Rabbinic expositions of scripture (Drake 2013:38-58). Even a dismembered and mutilated Paul, however, overcomes the heretics.

It is important to note, however, that Chrysostom's invective against Manichaean ascetic rigorism takes shape in the context of discussions about the responsibilities and limits of human freedom of choice, or $\pi \rho 0 \alpha i p \varepsilon \sigma 1 \varsigma$ (see esp. In Matthaeum homilia 49.3; Laird 2012:110-111). While there is much debate about the specifics and ideological varieties, Manichaeism may have generally held the opinion that although human beings have freedom of choice, the departure of the soul from the divine and the inherently evil nature of materiality, and the influence and compulsion of evil beings on human subjects, limited the responsibility of each individual's freedom of moral choice (Stock 2010:151-153). In many Christian-Manichaean exchanges, the debate was on the role me, and for pointing out some of these important sources relating to castration in late antique Syria.

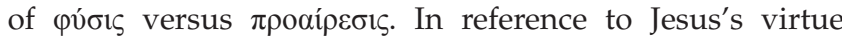
teaching, Chrysostom comments (In Matthaeum homilia 58.3; Greek text in Migne 1862:58:569):

Do you see how again he calls us to all the natural virtues [ $\tau \grave{\alpha}$

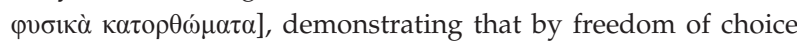
[ wicked madness of the Manichaeans? For if nature [i $\left.\left.\varphi v \sigma^{\sigma} \iota\right)\right]$ is something evil, why does he deduce from this concept his

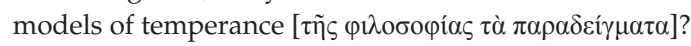

Chrysostom also positions himself against Manichaean teachings on the grace and call of God (BeDuhn 2013b:294295). In commenting on John 6:44, which reads, 'No one can come to me unless the Father who sent me draws them', he states (In Joannem homiliae 46.1; Greek text in Migne 1862:59:257):

The Manichaeans pounce on these words, saying that nothing lies in our own power. Yet the expression proves that we are

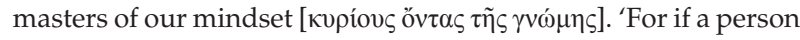
comes to Him', says someone, 'what need is there for drawing near?' But the words do not negate our free will, but show that we greatly need support. And he does not imply that the one who comes is unwilling, but someone who enjoys much assistance.

For Chrysostom, it is not an evil nature that leads human subjects into evil and wicked behaviour, but a corrupt

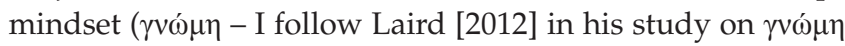
in Chrysostom in translating the word as 'mindset'). Thus, the body, which is part of the inherently good nature of God's creation, cannot be forced to goodness by means of corporeal

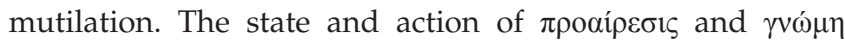
remain central and fundamental in human moral behaviour, yet $\varphi v ́ \sigma ı \varsigma$ is not inherently corrupt.

\section{The resurrection of the body}

All of the above discussions about the body and selfresponsibility lead us to a final and major dispute between Chrysostom and the Manichaeans, namely, the issue about the resurrection of the body. Manichaeans rejected the resurrection of the physical body, and rather opted for a type of psychic transmigration or metempsychosis, in which the pure soul, free from the bonds of matter, will ascend to the realm of light (Theodorou 2015:338-358). Again, Chrysostom groups the different heresies according to their similarities with regard to the resurrection of the body. In his 39th homily on 1 Corinthians, Chrysostom states that the Manichaeans only believe in a non-physical resurrection from sin. His most elaborate defence of the physical resurrection is found in his seventh sermon on Genesis, in which Chrysostom discusses the narrative of the robber on the cross, who Christ admits to Paradise (as per Lk 23:43) (In Genesim sermones 7.4; transl. Hill 2004:123; Greek text in Brottier 1998:332):

At this point pay attention: an issue arises that is not a chance one, namely the Manichees, stupid and rabid dogs, presenting an appearance of mildness but having on the inside savage fury of dogs, wolves in sheep's clothing. Lest you look to appearances, however, examine instead the wild beast hidden within. These 
people, then, seize upon this passage to claim that Christ said, 'Amen, amen, I say to you, this day you will be with me in paradise', so reward of good things has already been made, and resurrection in unnecessary; if the brigand was awarded good things that very day whereas his body has not yet risen even today, there will be no resurrection of the body in future.

In the broader argument Chrysostom provides in the sermon, the first response is to say that Paradise ( $\pi \alpha \rho \alpha \dot{\delta} \delta 1 \sigma o \zeta)$, here, does not refer to the kingdom of heaven (he states that some Manichaeans profess this interpretation of the verse). Chrysostom reminds his readers that Adam's garden, the $\pi \alpha \rho \alpha ́ \delta \varepsilon 1 \sigma 0 \zeta$, was not heaven. This stands in contrast to the notion of the New Paradise of Life in Manichaean thought, which was one of the three paths a soul could take after death. The robber therefore did not get to heaven and was not the recipient of the eschatological blessings of heaven. He only reaches paradise, at this stage, which is almost like a halfway house between this life and heaven. Secondly, and following the thought of Diodore of Tarsus and Theodore of Mopsuestia, both exegetes who gave preference to literal rather than allegorical readings of scripture, Chrysostom emphasises, especially in his 13th homily on Genesis, the belief that Paradise is a physical place on earth, and not an ethereal heavenly place (Reuling 2006:139). So, Paradise is part of the material realm, which supports Chrysostom's case for a bodily resurrection. The focus on the literal interpretation of Scripture serves in Chrysostom's interest when he refutes Manichaean understandings of paradise as heaven and the denial of the resurrection.

\section{Conclusion}

We may conclude, then, that Chrysostom possessed not an insignificant measure of knowledge about Manichaean dualism, and even seems to comment on their habitus. He states that Manichaeans appear pious, mild and meek, and even wear a mask of Christian identity. He says (In epistulam ad Hebraeos homiliae 8.8; Greek text in Migne 1862:63:73): 'For even Manichaeans, and all the heresies, have assumed this mask [of being Christian], so in order to deceive the more simple-minded ones'. He certainly does not display the type of detailed and nuanced insider knowledge we find in Augustine, but it is possible that Chrysostom had dealings with Manichaeans, especially while in Antioch, and possibly debated with Manichean intellectuals. It is highly likely that, especially while in Antioch, there may have been Manichaeans in his audience. In his homily against the Manichaeans and Marcionites, he explicitly states that there is a possibility that these heretics might be in his audience. This latter point is further supported by the fact that Chrysostom is acutely aware of the economy of scriptural proof-texting between Orthodox Christians and Manicheans one finds in other authors, like Augustine. He even provides mantra-like responses to his audience for when they might find themselves in a 'Manichaean encounter'.

Chrysostom also has knowledge about Manichaean ascetic practices, albeit biased, such as fasting, the sacred meal and sexual abstinence. He goes to great lengths, as we have seen, to discern between Christian and Manichaean ascetic practices. This could quite plausibly mean that the differences between Christian monks and the Manichaean Elect were not so apparent as some may think. Manichaeism was very much at home in Roman-Christian Syria. In their nascent stages, both ascetic groups may have been influenced by the same literary traditions, such as those of Tatian, Marcion, Bardaisan and Thomas literary tradition. Even if Chrysostom's statements about Manichaean fasting, as starvation, are not hyperbole, we hear similar accounts about Syrian Christian monks who practised rigorous fasting from sources like Theodoret's History of the Monks of Syria and John of Ephesus's Lives of the Eastern Saints, and even from Chrysostom himself (De Wet 2019:440-452). Even if Manichaeans did practise castration, so did some Christian monks. Thus, while literary sources like those of Chrysostom aim to highlight difference and distinction between these groups, the historical-cultural realities may have been less apparent. In broad perspective, though, we notice that Chrysostom certainly devotes much more time refuting Arianism and Judaism than he does Manichaeism.

\section{Acknowledgement Competing interest}

The author has declared that no competing interests exist.

\section{Author contributions}

I declare that I am the sole author of this research article.

\section{Funding}

Data sharing is not applicable to this article as no new data were created or analysed in this study.

\section{Data availability statement}

Data sharing is not applicable to this article as no new data were created or analysed in this study.

\section{Disclaimer}

The views and opinions expressed in this article are those of the authors and do not necessarily reflect the official policy or position of any affiliated agency of the authors.

\section{Ethical consideration}

This article followed all ethical standards for carrying out research without direct contact with human or animal subjects.

\section{References}

BeDuhn, J., 2000, The Manichaean body: In discipline and ritual, Johns Hopkins University Press, Baltimore, MD.

BeDuhn, J., 2007, 'A war of words: Intertextuality and the struggle over the legacy of Christ in the Acta Archelai', in J. BeDuhn \& P. Mirecki (eds.), Frontiers of faith: The Christian encounter with Manichaeism in the Acts of Archelaus, pp. 77-102, Brill, Leiden.

BeDuhn, J., 2013a, Augustine's Manichaean dilemma, volume 1: Conversion and apostasy, 373-388 C.E., University of Pennsylvania Press, Philadelphia, PA. 
BeDuhn, J., 2013b, Auqustine's Manichaean dilemma, volume 2: Making a 'Catholic' self, 388-401 C.E., University of Pennsylvania Press, Philadelphia, PA.

Brändle, R., 2004, John Chrysostom: Bishop-reformer-martyr, St. Paul's, Strathfield.

Brottier, L., 1998, Jean Chrysostome: Sermons sur la Genèse, Cerf, Paris.

Brown, P., 1969, 'The diffusion of Manichaeism in the Roman Empire', Journal of Roman Studies 59, 92-103. https://doi.org/10.2307/299850.

Caner, D.F., 1997, 'The practice and prohibition of self-castration in early Christianity', Vigiliae Christianae 51(4), 396-415. https://doi.org/10.2307/1583869

Coyle, J.K., 2009, Manichaeism and its legacy, Brill, Leiden.

De Wet, C.L., 2014, 'Identity-formation and the problem of alterity in John Chrysostom's homilies in Epistulam Ad Galatas commentarius', Acta Theologica Supplementum 19, 18-41. https://doi.org/10.4314/actat.v33i2S.2

De Wet, C.L., 2015, Preaching bondage: John Chrysostom and the discourse of slavery in early Christianity, University of California Press, Oakland, CA.

De Wet, C.L., 2019, 'The preacher's diet: Gluttony, regimen, and psycho-somatic health in the thought of John Chrysostom', in C.L. De Wet \& W. Mayer (eds.) Revisioning John Chrysostom: New approaches, new perspectives, pp. 410-463, Brill, Leiden.

Drake, S., 2013, Slandering the Jew: Sexuality and difference in early Christian texts, University of Pennsylvania Press, Philadelphia, PA.

Field, F., 1845, loannis Chrysostomi interpretatio omnium epistularum Paulinarum, vol. 3, J.H. Parker, Oxford.

Field, F., 1852, loannis Chrysostomi interpretatio omnium epistularum Paulinarum vol. 4, J.H. Parker, Oxford.

Franzmann, M., 2003, Jesus in the Manichaean writings, T\&T Clark, London.

Harkins, P., (trans.), 1984, St. John Chrysostom: On the incomprehensible nature of God, Catholic University of America Press, Washington, DC.

Hill, R., (trans.), 1999, St. John Chrysostom: Homilies on Genesis 1-17, Catholic University of America Press, Washington, DC.

Hill, R., (trans.), 2004, St. John Chrysostom: Eight sermons on the book of Genesis, Holy Cross Orthodox Press, Brookline, MA.

Kelly, J.N.D., 1998, Golden mouth: The story of John Chrysostom-Ascetic, preacher, bishop, Cornell University Press, Ithaca, NY.

Kósa, G., 2015, 'The Manichaean attitude to natural phenomena as reflected in the Berlin Kephalaia', Open Theology 1(1), 255-268. https://doi.org/10.1515/opth2015-0011
Laird, R.J., 2012, Mindset, moral choice and sin in the anthropology of John Chrysostom, St. Paul's, Strathfield.

Lieu, S.N.C., 1992, Manichaeism in the later Roman Empire and medieval China, Mohr Siebeck, Tübingen.

Lieu, S.N.C., 2008, 'Manichaeism', in S.A. Harvey \& D.G. Hunter (eds.), The Oxford handbook of early Christian studies, pp. 221-236, Oxford University Press, Oxford.

Lieu, S.N.C., 2015, Manichaeism in Mesopotamia and the Roman East, Brill, Leiden.

Lollar, J.B., 2018, 'A sanctifying myth: The Syriac History of John in its social, literary, and theological context', Unpublished PhD dissertation, Florida State University, Tallahassee, FL.

Mara, M.G., 2008, 'Aspetti della polemica antimanichea di Giovanni Crisostomo', in L. Padovese, Atti dell'undicesimo simposio Paolino: Paolo tra Tarso e Antiochia, pp. 195-199, Pontificia Università Antonianum, Rome.

Migne, J.-P., (ed.), 1862, Patrologiae cursus completus: Series Graeca, 162 vols., J.-P. Migne, Paris.

Phenix, R.R. \& Horn, C.B., (eds. \& trans.), 2017, The Rabbula corpus: Comprising the life of Rabbula, his Correspondence, a homily delivered in Constantinople, canons, and hymns, SBL Press, Atlanta, GA.

Reuling, H., 2006, After Eden: Church fathers and rabbis on Genesis 3:16-21, Brill, Leiden.

Shahîd I. 1984, Rome and the Arabs: A prolegomenon to the study of Byzantium and the Arabs, Dumbarton Oaks Research Library and Collection, Washington, DC.

Shaw, T.M., 1998, The burden of the flesh: Fasting and sexuality in early Christianity, Fortress, Minneapolis, MN.

Stock, B., 2010, Augustine's inner dialogue: The philosophical soliloquy in late antiquity, Cambridge University Press, Cambridge.

Tardieu, M., 2008, Manichaeism, University of Illinois Press, Urbana, IL.

Theodorou, C., 2015, 'The concept of body and the body of Christ in the Manichaean Coptic Psalm-Book', in S.G. Richter, C. Horton \& K. Ohlhafer, (eds.), Mani in Dublin, pp. 338-358, Brill, Leiden.

Van Oort, J., 2013. 'God, memory and beauty: A Manichaean analysis of Augustine's Confessions, Book X', HTS Theological Studies 69, 1, 1-8.

Verheyden, J., Bieringer, R., Schröter, J. \& Jäger, I. (eds.), 2018, Docetism in the early church: The quest for an elusive phenomenon, Mohr Siebeck, Tübingen.

Wilson, K.M., 2018, Augustine's conversion from traditional free choice to 'non-free free will': A comprehensive methodology, Mohr Siebeck, Tübingen.

Woods, D., 2001, 'Strategius and the "Manichaeans"', Classical Quarterly 51, 1 , 255-264. 